\title{
Rate of Tomato yellow leaf curl virus Translocation in the Circulative Transmission Pathway of its Vector, the Whitefly Bemisia tabaci
}

\author{
Murad Ghanim, Shai Morin, and Henryk Czosnek
}

Department of Field Crops and Genetics and the Otto Warburg Centre for Biotechnology in Agriculture, Faculty of Agriculture, Food and Environmental Quality Sciences, The Hebrew University of Jerusalem, Rehovot 76100, Israel. Accepted for publication 17 October 2000.

\begin{abstract}
Ghanim, M., Morin, S., and Czosnek, H. 2001. Rate of Tomato yellow leaf curl virus translocation in the circulative transmission pathway of its vector, the whitefly Bemisia tabaci. Phytopathology 91:188-196.

Whiteflies (Bemisia tabaci, biotype B) were able to transmit Tomato yellow leaf curl virus (TYLCV) $8 \mathrm{~h}$ after they were caged with infected tomato plants. The spread of TYLCV during this latent period was followed in organs thought to be involved in the translocation of the virus in B. tabaci. After increasing acquisition access periods (AAPs) on infected tomato plants, the stylets, the head, the midgut, a hemolymph sample, and the salivary glands dissected from individual insects were

subjected to polymerase chain reaction (PCR) without any treatment; the presence of TYLCV was assessed with virus-specific primers. TYLCV DNA was first detected in the head of B. tabaci after a 10-min AAP. The virus was present in the midgut after $40 \mathrm{~min}$ and was first detected in the hemolymph after $90 \mathrm{~min}$. TYLCV was found in the salivary glands $5.5 \mathrm{~h}$ after it was first detected in the hemolymph. Subjecting the insect organs to immunocapture-PCR showed that the virus capsid protein was in the insect organs at the same time as the virus genome, suggesting that at least some TYLCV translocates as virions. Although females are more efficient as vectors than males, TYLCV was detected in the salivary glands of males and of females after approximately the same AAP.
\end{abstract}

Tomato yellow leaf curl virus (TYLCV) is the name given to a complex of geminiviruses (family Geminiviridae, genus Begomovirus) affecting tomato cultures worldwide $(11,12)$. TYLCV has a monopartite genome (30) and is transmitted by the whitefly Bemisia tabaci in a persistent circulative manner $(10,34)$.

Parameters of acquisition and transmission of TYLCV by adult B. tabaci have been studied in depth $(1,10,24,25,36)$. Single insects are able to acquire TYLCV and transmit it to tomato plants. In a one insect/one plant inoculation test, female $B$. tabaci are more efficient than male insects (10). Minimum acquisition access periods (AAP) and inoculation access periods (IAP) are approximately 10 to $20 \mathrm{~min}$. The rate of transmission increases with longer AAPs and IAPs. The minimal latent period reported was $21 \mathrm{~h}$ (10) but was $24 \mathrm{~h}$ for the closely related TYLCV strain from Egypt (25) and $17 \mathrm{~h}$ for the more distant virus from Sardinia (6) .

The geminiviral coat protein $(\mathrm{CP})$ possesses determinants needed for virus acquisition and transmission by the insect vector. Exchanging the $\mathrm{CP}$ gene of the whitefly-transmitted African cassava mosaic virus (ACMV) with that of the leafhopper-transmitted Beet curly top virus (genus Curtovirus) produced a leafhoppertransmitted ACMV chimera (4). Replacing the CP of the nontransmissible Abutilon mosaic virus (AbMV) with that of the transmissible Sida golden mosaic virus produced a whitefly-transmissible chimeric AbMV (21). Mutating the CP gene of Bean golden mosaic virus resulted in the loss of acquisition by $B$. tabaci (2). Two amino acid replacements in the CP of TYLCSV abolished virus transmission by $B$. tabaci but not its acquisition (32). Insect proteins also play a role in virus transmission. A GroEL homologue produced by the coccoid endosymbionts of $B$. tabaci is involved in the circulative transmission of TYLCV (26).

Corresponding author: H. Czosnek: E-mail address: czosnek@agri.huji.ac.il

Publication no. P-2000-1127-02R

(C) 2001 The American Phytopathological Society
Geminiviruses translocation in their insect vector is still not fully understood. A parallel has been drawn between transmission of luteovirus and geminivirus, suggesting that these viruses move out of the gut into the haemocoel on their way to the salivary glands (20). Anatomical and immunolocalization studies performed during the last few years have allowed us to better understand the circulative pathway of geminiviruses in their whitefly vector $(18,19,22)$. As observed for luteoviruses in aphids (15-17), geminivirus particles are thought to be ingested along with phloem sap of infected plants through the stylets and enter the esophagus and the filter chamber. Virions are subsequently transported through the gut wall into the hemocoel and from there they reach the salivary glands. The virus is translocated into the salivary duct and is finally excreted with the saliva during feeding. The time it takes for a geminivirus to complete this path is reflected in the minimal period of time that elapses from beginning of feeding on infected plants to transmission to test plants (latent period). The development of polymerase chain reaction (PCR) has been instrumental in analyzing the velocity of geminivirus translocation in $B$. tabaci. Using print capture-PCR, TYLCV DNA was detected in the head of whiteflies as early as after a 5-min AAP on infected tomato plants, in the thorax after $10 \mathrm{~min}$, and in the abdomen after $25 \mathrm{~min}$. TYLCV DNA was detectable in test plants as early as after a 5-min IAP (1). In another investigation, the transmission pathway of the Squash leaf curl virus (SLCV) was traced by DNA from $B$. tabaci extracts, saliva, hemolymph, and honeydew as substrate for PCR (33). SLCV was detected in insect extracts after a 30 min AAP on infected pumpkin. The virus was found in the hemolymph after $2 \mathrm{~h}$ and in the saliva and honeydew after $8 \mathrm{~h}$. In the same study, the whitefly Trialeurodes vaporariorum was able to acquire but not transmit SLCV. In this insect, SLCV was not detected in the hemolymph and in the saliva.

In the present study, we asked the question of whether the Old World monopartite TYLCV transits through the same organs and with the same velocity as the New World bipartite SLCV. Using 
whitefly stylets, head, midgut, hemolymph, and salivary glands dissected from a single insect as substrate for PCR and immunocapture-PCR, we have determined the timing of TYLCV translocation and passage from one organ through another, from acquisition to transmission.

\section{MATERIALS AND METHODS}

Maintenance of virus cultures, whiteflies, and plants. Cultures of an Israeli isolate of TYLCV (30) were maintained in tomato plants (Lycopersicon esculentum cv. Daniella). Whiteflies, B. tabaci, B biotype (7), were reared on cotton plants (Gossypium hirsutum cv. Akala) grown in insect-proof wooden cages at 24 to $27^{\circ} \mathrm{C}$ (36). Unless specified otherwise, all insects used were females.

Acquisition of TYLCV by adult insects. All experiments were conducted in insect-proof wooden cages kept at 24 to $27^{\circ} \mathrm{C}$ in an insect-proof growth chamber. TYLCV was acquired by whiteflies 5 to 8 days after emergence. The insects were caged with the youngest true leaf from the infected tomato plant (at the five- to seven-leaf stage, 6 weeks after whitefly-mediated inoculation) for the AAP indicated in the experiments.

Determination of the latent period. The latent period was determined in two different ways. In the first experiment, approximately 1,000 whiteflies were caged with infected tomato plants for a 2-h AAP. The insects were then collected with a mouth aspirator and caged with 10 uninfected tomato test plants (at the fiveleaf stage). After an IAP of $1 \mathrm{~h}$, the insects were collected and caged with a second group of 10 tomato test plants for an additional 1-h IAP. The first 10 plants were treated with the insecticide Talstar 35 (active ingredient: bifenthrin; FMC Corporation, Rockland, ME) to ensure that no insect was left alive. The insects were collected from the second group of plants after the 1-h IAP and caged with a third group of 10 plants. The procedure was repeated until the insects were serially transferred to 13 groups of 10 plants. Plants from groups 1 to 8 were caged with the whiteflies for a 1-h IAP, plants from group 9 were caged with insects for a 2-h IAP, plants from groups 10 to 12 for a 4-h IAP, and plants from group 13 were caged with insects for a 24-h IAP. After each transfer, we made sure that each plant beared at least 10 whiteflies.

In the second experiment, approximately 2,000 whiteflies caged with infected tomato plants for a 2-h AAP were distributed among 13 groups of 10 plants each, ensuring that each plant had at least 10 insects. The insects were removed from each group of plants after $1,2,3,4,5,6,7,8,10,14,18,22$, or $48 \mathrm{~h}$, and the plants were treated with insecticide. The appearance of symptoms was monitored during 5 weeks, and the presence of viral DNA was assessed by squash blot hybridization 14 days postinoculation (29).

Dissection of organs from single whiteflies. After a given access period, the insects were collected by aspiration and exposed to acetone vapors for 2 to $3 \mathrm{~min}$ to arrest movement. The insects were dissected on a glass slide under a binocular microscope $(\times 40)$. Dissections were performed in insect physiological saline (IPS: $4.5 \mathrm{~g}$ of $\mathrm{NaCl}, 0.1 \mathrm{~g}$ of $\mathrm{KCl}, 0.1 \mathrm{~g}$ of $\mathrm{CaCl}_{2}, 0.1 \mathrm{~g}$ of $\mathrm{MgCl}_{2}, 0.1 \mathrm{~g}$ of $\mathrm{NaHCO}_{3}$, and $2.0 \mathrm{~g}$ of glucose, per liter) with or without $1 \%$ toluidine blue, on a glass slide as described (3). The isolated tissues were placed in a PCR test tube containing $3 \mu \mathrm{l}$ of sterile double distilled water (ddw). To dissect the midgut, the abdomen was separated from the thorax at the connection between them. Its content was expelled in a drop of IPS (without toluidine blue) by pushing gently on the abdomen. The midgut was isolated, cleaned from other tissues, flushed several times with ddw, and collected with a fine metallic thread fixed on a wooden handle. To isolate the salivary glands, the prothorax was separated from the mesothorax and abdomen. The glands were teased away from the body and kept for 2 to $5 \mathrm{~min}$ in IPS-toluidine blue until they absorbed the dye, allowing identification and dissection. The pair of primary glands and the much smaller adjacent secondary salivary glands were flushed several times with ddw and collected. The stylets were pulled out from the whole head. Hemolymph was extruded and collected with a glass micropipette as described (26).

Observation of $B$. tabaci organs with the scanning electron microscope. Insects were dissected as described above with the exception that they were first placed on a microscope cylindrical mount using double-sided adhesive tape. The organ of interest (midgut, salivary glands, or stylets) was washed several times with distilled water by a Pasteur pipette with a narrow tip and fixed for 3 to $5 \mathrm{~min}$ with $2.5 \%$ glutaraldehyde and $4 \%$ paraformaldehyde in phosphate-buffered saline, as described (28). The sample was incubated with hexamethyldisilazane for 45 min two times, allowed to air dry for $18 \mathrm{~h}$, and observed in a low vacuum scanning electron microscope (JOEL 5410, Tokyo).

Amplification of TYLCV DNA by PCR with organs dissected from single whiteflies as substrate. The insect organs, without any further treatment, were subjected to PCR $(20-\mu \mathrm{l} \mathrm{reac}$ tion). $A \approx 410$-bp TYLCV DNA fragment was amplified by two primers designed from the nucleotide (nt) sequence of the TYLCV genome (30): V61 (nt 61-80, viral strand, 5'ATACTTGGACACCTAATGGC3') and C473 (nt 473-457, complementary strand, 5'AGTCACGGGCCCTTACA3'). Oligonucleotides were purchased from Biotechnology General, Rehovot, Israel. The cycling protocol (using a Techne PHC-2 thermocycler) was as follows: initial denaturation for $3 \mathrm{~min}$ at $95^{\circ} \mathrm{C}$, annealing of primers for $1 \mathrm{~min}$ at $55^{\circ} \mathrm{C}$, extension for $2 \mathrm{~min}$ at $72^{\circ} \mathrm{C}$, and denaturation for $1 \mathrm{~min}$ at $94^{\circ} \mathrm{C}$; subsequent cycles were: $1 \mathrm{~min}$ at $55^{\circ} \mathrm{C}$, $2 \mathrm{~min}$ at $72^{\circ} \mathrm{C}$, and $1 \mathrm{~min}$ at $94^{\circ} \mathrm{C}$; after 30 cycles, the reaction was terminated by a 10 -min incubation at $72^{\circ} \mathrm{C}(31)$. The PCR products were analyzed by electrophoresis in a $1 \%$ agarose gel and photographed. The amplified virus DNA was identified after blotting, and hybridization with plasmid pTYH19 containing a full-length copy of the TYLCV genome labeled with ${ }^{32} \mathrm{P}-\mathrm{dCTP}$ by a random-primed DNA labeling kit (Boehringer $\mathrm{GmbH}$, Mannheim, Germany) (30). Autoradiography was for 1 to $8 \mathrm{~h}$ with X-ray films (Fuji) or 1 to $2 \mathrm{~h}$ with a Phosphor imager (FujiX-Bio Imaging Analyzer, IPR-1000; Fuji, Tokyo).

Detection of TYLCV CP. The virus CP was detected by immunocapture-PCR (23) by an antibody raised against the CP of a TYLCV isolate from the Dominican Republic overexpressed in Escherichia coli (provided by R. Gilbertson). The buffers used for immunocapture-PCR are described and were used as indicated by the manufacturer (Bioreba, Ebringen, Germany). PCR tubes were filled with $200 \mu \mathrm{l}$ of antiserum (1:1,000 diluted in coating buffer), incubated for $3 \mathrm{~h}$ at $37^{\circ} \mathrm{C}$ and washed five times for $5 \mathrm{~min}$ each with $200 \mu \mathrm{l}$ of washing buffer. Whitefly or plant homogenates in $200 \mu \mathrm{l}$ of extraction buffer were incubated in the coated PCR tubes for $18 \mathrm{~h}$ at $4^{\circ} \mathrm{C}$. The tubes were washed five times for $5 \mathrm{~min}$ each with $200 \mu \mathrm{l}$ of washing buffer and dried. PCR-amplification of the viral DNA from the virions bound to the antibody-coated tubes was performed with the TYLCV specific primers V61 and C473 (13).

\section{RESULTS}

Whiteflies efficiently transmit TYLCV to tomato test plants $8 \mathrm{~h}$ after they started to acquire virus. We have determined the latent period using two different ways. In the first experiment, whiteflies provided access to infected tomato plants for $2 \mathrm{~h}$ and were caged with uninfected tomato tests plants. They were transferred serially to new test plants at 1-h intervals, until $10 \mathrm{~h}$ after the beginning of the initial AAP (later the IAPs lasted longer). In the second experiment, whiteflies that accessed the infected tomato plants for $2 \mathrm{~h}$ were caged with the test plants for IAPs of increasing length, from 1 to $46 \mathrm{~h}$. The results summarized in Table 1 show that in both experiments, whiteflies were able to transmit the virus $8 \mathrm{~h}$ after the start of the AAP, as determined by subse- 
quent appearance of symptoms and of viral DNA. The rate of plant infection raised as the time span between the beginning of the AAP and the end of the IAP increased. Uninfected test plants remained symptomless and devoid of TYLCV DNA. These results showed that in our hands the latent period was $8 \mathrm{~h}$.

TYLCV DNA detection by PCR in organs dissected from a single viruliferous whitefly. Organs of the whitefly vector believed to participate in the acquisition/transmission pathway of TYLCV were dissected. Because of the rather tight timing of translocation and the fragility of the tissues, we needed to ensure that virus movement was arrested at the time of sampling the insects. We found that using acetone vapors was adequate. Whereas the midgut of insects processed this way is immobile, that of whiteflies treated with $\mathrm{CO}_{2}$ is still contracting. Freezing insects for a short time did not prevent the pumping movements that resumed under the heat of the binocular light. Freezing the insects for long periods of time also produced damage to the tissues.

Figure 1 (upper panel) shows the isolated stylets, digestive tract, and salivary glands, as observed with the scanning electron microscope. The major elements of the stylets can be seen, including the labium (outside the head) and the stylet bundle (inside the head), together with the cibarial pump protractor muscles. The digestive tract includes the midgut (descending and ascending), the hindgut, the caeca, and the filter chamber. For PCR studies, the hindgut was severed from the midgut and discarded. One of the pair of primary salivary glands is shown; in the PCR studies, both glands were used, together with the pair of secondary salivary glands.

Organs isolated from a single viruliferous whitefly served as a sufficient source of template DNA for PCR detection of TYLCV DNA. Except for washing thoroughly the midgut and salivary glands, there was no need to treat the organs in any way before subjecting them to the PCR. Attempts to extract DNA from these organs and using this DNA as substrate in the PCR provided poor results; the viral DNA was amplified with a frequency much lower than that obtained with untreated organs. Female whiteflies were caged with infected tomato plants. After a 12-h AAP, the stylets, the midgut, a hemolymph drop, and the salivary glands were isolated from a single insect and subjected to PCR by the TYLCV-specific primer pair V61 and C473. One nonviruliferous and two viruliferous whiteflies were analyzed. Figure 1 (lower panel) shows that the expected $\approx 410$-bp viral DNA fragment was amplified from each of the organs isolated from the two viruliferous insects assayed, but not from a nonviruliferous insect. The identity of the amplified viral DNA fragment was confirmed by hybridization with a TYLCV DNA probe.
Temporal detection of TYLCV DNA in the stylet, head, midgut, hemolymph, and salivary glands of single whiteflies, as a function of the AAP. Female whiteflies were caged with infected tomato plants for various AAPs, from $5 \mathrm{~min}$ to $24 \mathrm{~h}$. Ten insects were analyzed individually for each time point. After a given AAP, whiteflies were collected, exposed to acetone vapors and immediately dissected. The stylet, the head (without the stylet), the midgut, a drop of hemolymph, and the salivary glands from each one of the 10 insect were subjected to PCR by the TYLCV-specific primer pair V61 and C473. Figure 2 shows the PCR products obtained with the selected organs of one representative whitefly for each of the AAPs. Figure 3 summarizes the results obtained after analyzing the organs of 10 insects for each AAP.

TYLCV DNA was undetectable in the insects after an AAP of 5 min (Fig. 3) as well as in nonviruliferous insects (Fig. 2), confirming that whiteflies from the insect colony were virus-free. As shown in Figure 3, we were unable to detect viral DNA in the stylets for up to $2 \mathrm{~h}$ of acquisition feeding ( 1 of 10 samples tested contained detectable viral DNA at this time). The efficiency of detection of viral DNA in the stylet did increase with time, but was very erratic. TYLCV DNA was never detected in the stylet of all 10 insects sampled, even after a 9-h AAP when the virus DNA was found in the head and midgut of all insects tested.

Viral DNA was detected in the head of the insect (minus the stylets) after a 10-min AAP (in 3 of 10 insects) but was not detected in any of the samples tested after a 5-min AAP. Because the stylet and the salivary glands were removed, we assume that virus was present only in the small segment of esophagus remaining in the head. The frequency of detection of TYLCV DNA in the whitefly head increased with the AAP. It certainly reflected the time when the individual insects started to feed on the infected plant. At $3 \mathrm{~h}$, all 10 insects had acquired the virus. It should be noted that even after relatively long AAP, based on visual observation, some insects still were not feeding on infected tomato tissues (insect six at $7 \mathrm{~h}$; insect eight at $8 \mathrm{~h}$; and insects five and eight at $12 \mathrm{~h}$ ).

As the length of the AAP increased, viral DNA was found in the midgut, then in the hemolymph, and finally in the salivary glands. Once acquired, TYLCV enters the digestive system via the esophagus, reaches the filter chamber and the midgut. Whether the virus spreads beyond the anterior part of the midgut is not known. TYLCV DNA was first found in the insect midgut after an AAP of $40 \mathrm{~min}$. At this time the midgut of 2 of the 10 whiteflies analyzed contained detectable viral DNA. The virus was still not detectable in the midgut after an AAP of $20 \mathrm{~min}$. We used five

TABLE 1. Determination of the latent period of Tomato yellow leaf curl virus in the whitefly Bemisia tabaci

\begin{tabular}{|c|c|c|c|c|c|}
\hline \multicolumn{3}{|c|}{ Experiment 1} & \multicolumn{3}{|c|}{ Experiment 2} \\
\hline Time after AAP started (h) ${ }^{\mathrm{a}}$ & Successive IAP $(h)^{b}$ & Infection rate ${ }^{c}$ & Time after AAP started $(\mathrm{h})^{\mathrm{a}}$ & Length of IAP $(h)^{d}$ & Infection rate ${ }^{c}$ \\
\hline 0 & 0 & $0 / 10$ & 0 & 0 & $0 / 10$ \\
\hline 3 & 1 & $0 / 10$ & 3 & 1 & $0 / 10$ \\
\hline 4 & 1 & $0 / 10$ & 4 & 2 & $0 / 10$ \\
\hline 5 & 1 & $0 / 10$ & 5 & 3 & $0 / 10$ \\
\hline 6 & 1 & $0 / 10$ & 6 & 4 & $0 / 10$ \\
\hline 7 & 1 & $0 / 10$ & 7 & 5 & $0 / 10$ \\
\hline 8 & 1 & $5 / 10$ & 8 & 6 & $3 / 10$ \\
\hline 9 & 1 & $7 / 10$ & 9 & 7 & $4 / 10$ \\
\hline 10 & 1 & $6 / 10$ & 10 & 8 & $4 / 10$ \\
\hline 12 & 2 & $8 / 10$ & 12 & 10 & $6 / 10$ \\
\hline 16 & 4 & $8 / 10$ & 16 & 14 & $5 / 10$ \\
\hline 20 & 4 & $9 / 10$ & 20 & 18 & $8 / 10$ \\
\hline 24 & 4 & $9 / 10$ & 24 & 22 & $8 / 10$ \\
\hline 48 & 24 & $10 / 10$ & 48 & 46 & $10 / 10$ \\
\hline
\end{tabular}

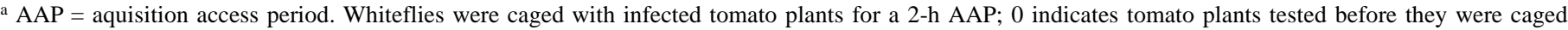
with viruliferous whiteflies.

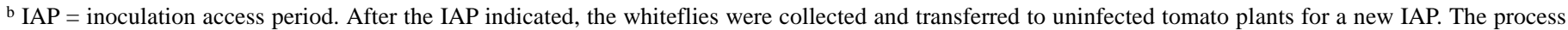
was repeated until 12 groups of 10 test plants were treated.

c Number of infected plants per total plants.

d Following the 2-h AAP, the whiteflies were distributed among groups of 10 plants for the IAPs indicated. 
insects to determine that viral DNA was undetectable after an AAP of $30 \mathrm{~min}$ (data not shown). After a 40-min AAP, the frequency of TYLCV DNA amplification increased with the length of the AAP. Viral DNA was found in the midgut of 8 of the 9 insects containing viral DNA after an AAP of $2 \mathrm{~h}$ and in all 10 insects analyzed after $3 \mathrm{~h}$. These results showed that TYLCV reached the midgut approximately $30 \mathrm{~min}$ after it was first detected in the head of the insect.

The suggested pathway of a begomovirus in its whitefly vector involves a step where the virus crosses the gut walls and enters the hemolymph (20). Figure 3 shows that TYLCV DNA was first detected in the whitefly midgut after a 30-min AAP. At this time, TYLCV was not detected in the hemolymph. TYLCV DNA was amplified from the hemolymph of viruliferous whiteflies after an AAP of $2 \mathrm{~h}$. Three hemolymph samples of the 10 analyzed contained detectable TYLCV DNA at this time. The viral DNA was never detected in the hemolymph after a 1-h AAP. To determine more precisely the time when TYLCV crosses the gut/hemolymph barrier, these tissues were analyzed every $15 \mathrm{~min}$, between 1 and 2 $\mathrm{h}$ of AAP. Figure 4 shows that TYLCV was detected in the hemolymph $30 \mathrm{~min}$ after it was first detected in the midgut, i.e., 90 min after the beginning of acquisition feeding.

Once in the hemolymph, begomoviruses reach the salivary glands where they are inoculated into plants with saliva. Whereas TYLCV DNA was detected in the hemolymph after a $90 \mathrm{~min}$ AAP, the virus was not found in any of the salivary gland samples for up to $7 \mathrm{~h}$ (Fig. 3). At this time, the salivary gland of 2 of the 10 insects tested contained detectable viral DNA. Therefore, the transit of the virus into the salivary gland constitutes the longest phase in the circulative transmission process. The frequency of virus detection in salivary glands increased with time; nevertheless, the virus was not detected in all the insects tested in any of the groups, even after AAPs of $10 \mathrm{~h}$ and more. The time the viral DNA was first detected in the salivary gland was very close to the 8-h latent period. Hence, it seems that enough virus reaches the salivary gland during an 8-h AAP to exceed the threshold of infectivity.

Detection of TYLCV DNA associated with the virus CP in the stylet, head, midgut, hemolymph, and salivary glands. We do not know how and in which form (naked DNA, virion, nucleoprotein) TYLCV or any other begomovirus translocates in its vector. We have followed the translocation of TYLCV DNA associated with the virus CP using the immunocapture-PCR technique. The CP-DNA complex (possibly virions) contained in homogenates of whitefly tissues binds to a $\mathrm{CP}$ antibody coating a test tube. The bound complex is then heat-disrupted, and the viral genome is amplified by PCR.

Because this immunocapture-PCR is less sensitive than PCR, samples extracted from 25 insects were pooled and assayed. Figure 5 shows that a positive signal was found in the stylets, head, and midgut of insects after a 1-h AAP, but not in the hemolymph or the salivary glands. After $2 \mathrm{~h}$, the virus was also detected in the hemolymph, but still not in the salivary glands. After $12 \mathrm{~h}$, the virus was detected in the salivary glands. In all cases, detection of TYLCV was dependent on the presence of the antibody. TYLCV DNA was not amplified when the antibody was omitted (Fig. 5).
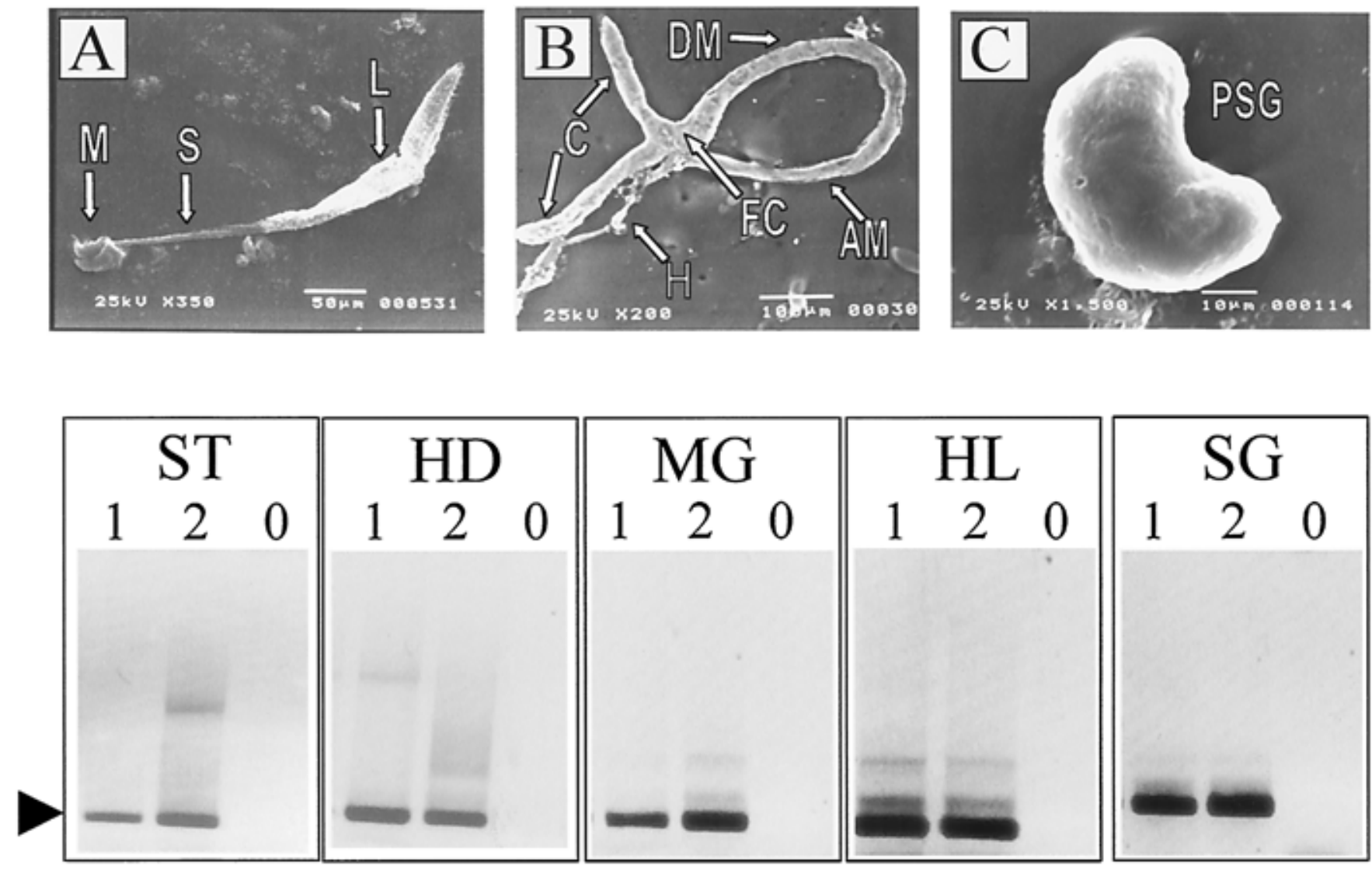

Fig. 1. Top panel: Scanning electron micrographs of organs involved in the circulative transmission pathway of Tomato yellow leaf curl virus (TYLCV) isolated from whiteflies. A, Stylet; L = labium (outside the head), $\mathrm{S}=$ stylet bundle (inside the head), and M = cibarial pump protractor muscles. B, Digestive tract; DM and $\mathrm{AM}=$ descending and ascending midgut, $\mathrm{H}=$ hindgut, $\mathrm{C}=$ cacea, and $\mathrm{FC}=$ filter chamber. $\mathrm{C}$, Salivary gland; PSG $=$ one of the pair of primary salivary glands. Bottom panel: Detection of TYLCV by subjecting the stylets (ST), the head (HD), the midgut (MG), a hemolymph drop (HL), and the salivary glands (SG) to the polymerase chain reaction with the TYLCV-specific primer pair V61 and C473. All samples were dissected from a single viruliferous insect after a 12-h acquisition access period on an infected tomato plant. Two viruliferous whiteflies ( 1 and 2 ) and one nonviruliferous insect ( 0 ) were processed. The products of the reaction were subjected to agarose gel electrophoresis, blotted and hybridized with a virus-specific DNA probe. The arrow points to the $\approx 400$-bp amplified viral DNA fragment. 
Therefore the viral DNA associated with the CP was detected by immunocapture-PCR at the same time the virus genome was detected by PCR. These results suggest that at least part of the TYLCV DNA that translocates in the insect is encapsidated in a virion.

TYLCV translocates with the same velocity in males and females. Females transmit TYLCV with higher efficiency than males (10). In our study, one female (1 week after emergence) was enough to infect a tomato test plant, whereas five males of the same age are needed to achieve the same results (M. Ghanim and H. Czosnek, unpublished data). The reason for this difference is not known. We investigated the possibility that TYLCV reaches the salivary glands of females earlier than that of males. The midgut and salivary glands of females and males were subjected to PCR after a 7-h AAP, at a time when the virus appeared in the salivary glands of the female insects (Fig. 3). Figure 6 shows that

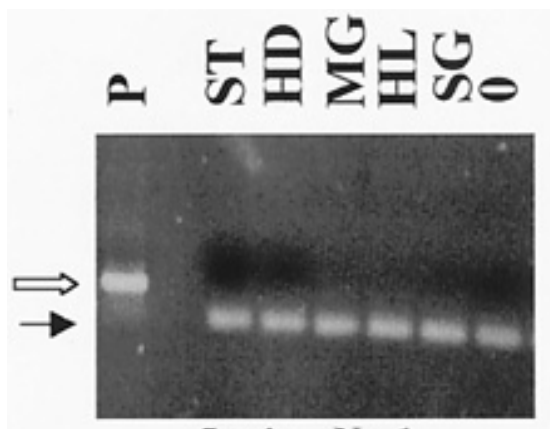

$5 \mathrm{~min}-$ No 1

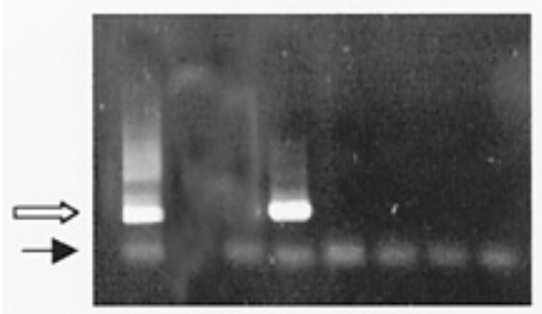

$10 \mathrm{~min}-\mathrm{No} 8$

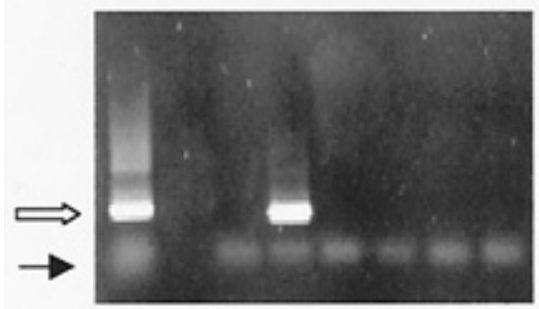

$20 \mathrm{~min}-\mathrm{No} 2$

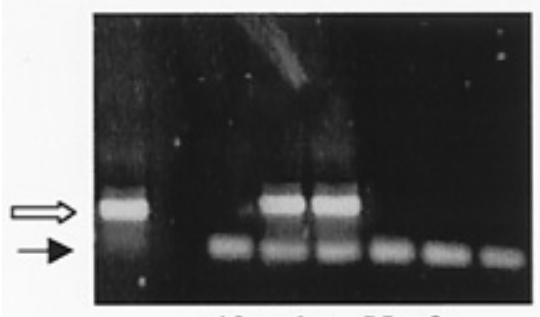

$40 \mathrm{~min}-$ No 9

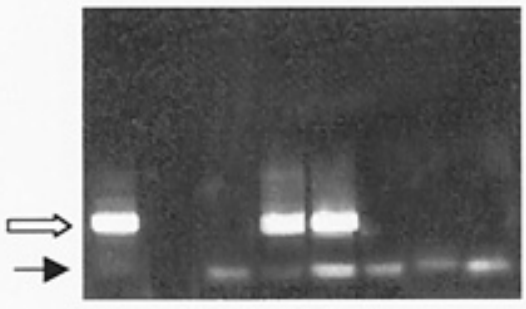

1 h - No 10

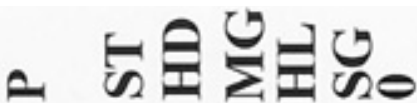

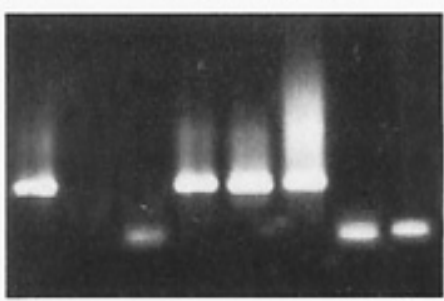

2 h - No 3

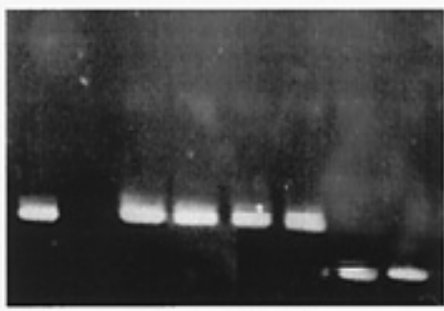

3 h - No 9

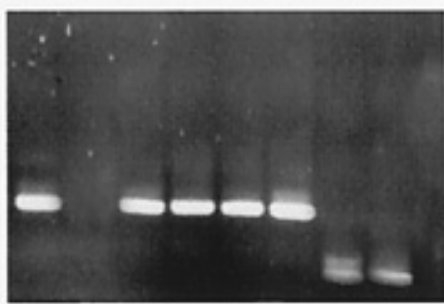

4 h - No 4

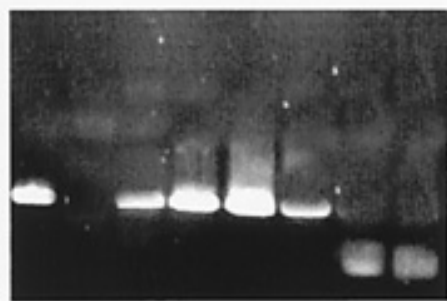

$6 \mathrm{~h}-\mathrm{No} 4$

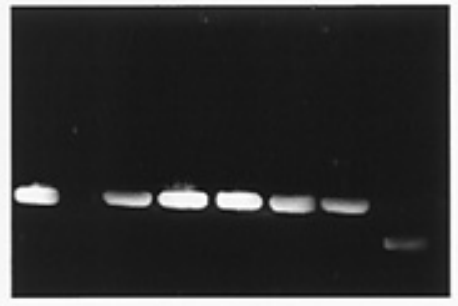

7 h - No 4
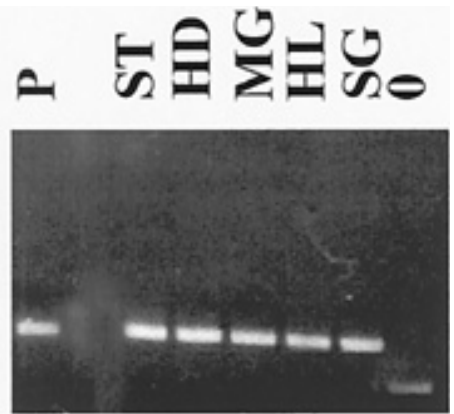

8 h - No 3

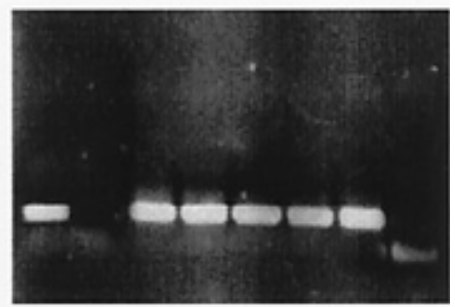

9 h - No 5

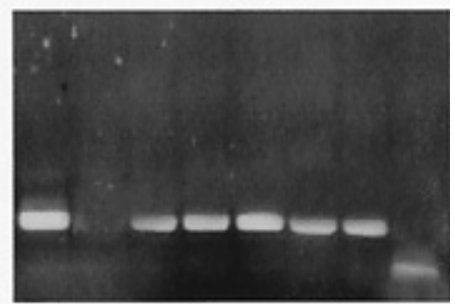

$10 \mathrm{~h}-$ No 10

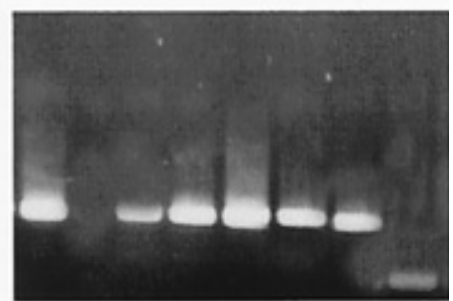

12 h - No1

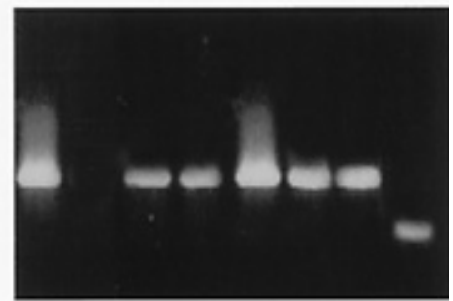

24 h - No 4

Fig. 2. Presence of Tomato yellow leaf curl virus (TYLCV) DNA in the stylets (ST), head (HD), midgut (MG), hemolymph (HL), and salivary glands (SG) of single whiteflies, as a function of the length of the acquisition access period (AAP) on infected tomato plant. All samples were dissected from a single insect after the indicated AAPs. The organs were subjected to polymerase chain reaction by the TYLCV-specific primer pair V61 and C473. The products of the reaction were examined by agarose gel electrophoresis and stained with ethidium bromide. $\mathrm{P}=$ plasmid pTYH20.7 containing the TYLCV DNA clone; $0=$ nonviruliferous insects. The thick arrow points to the amplified $\approx 410$-bp viral DNA fragment; thin arrow points to the position of the primers. The number of the insect refers to one of the 10 whiteflies tested for each AAP (Fig. 3). 
the virus was detected in the midgut of the two insects tested; the rate of detection of TYLCV DNA in the salivary gland of the females was equal to that of the males (three of four). Therefore TYLCV reaches the salivary gland at approximately the same time in male and female whiteflies.

\section{DISCUSSION}

Begomoviruses are transmitted by their whitefly vector in a circulative manner. Similar to the model proposed for luteovirus translocation in aphids (15-17), it is not likely that geminiviral particles ingested through the stylets enter the esophagus and the digestive tract, then penetrate the gut membranes into the hemolymph, reach the salivary glands, and finally enter the salivary duct from where they are ejected with the saliva $(18,19,22,33)$. Values given for the time necessary to complete the acquisition/inoculation pathway, the latent period, vary from 7 (27) to $24 \mathrm{~h}(8,9)$. This wide range of values may reflect the efficiency with which a given virus establishes a systemic infection in a plant rather than differences in the velocity of translocation in the insect vector. In this study we found a much shorter latent period for TYLCV from Israel than that reported 25 years ago, $8 \mathrm{~h}$ versus
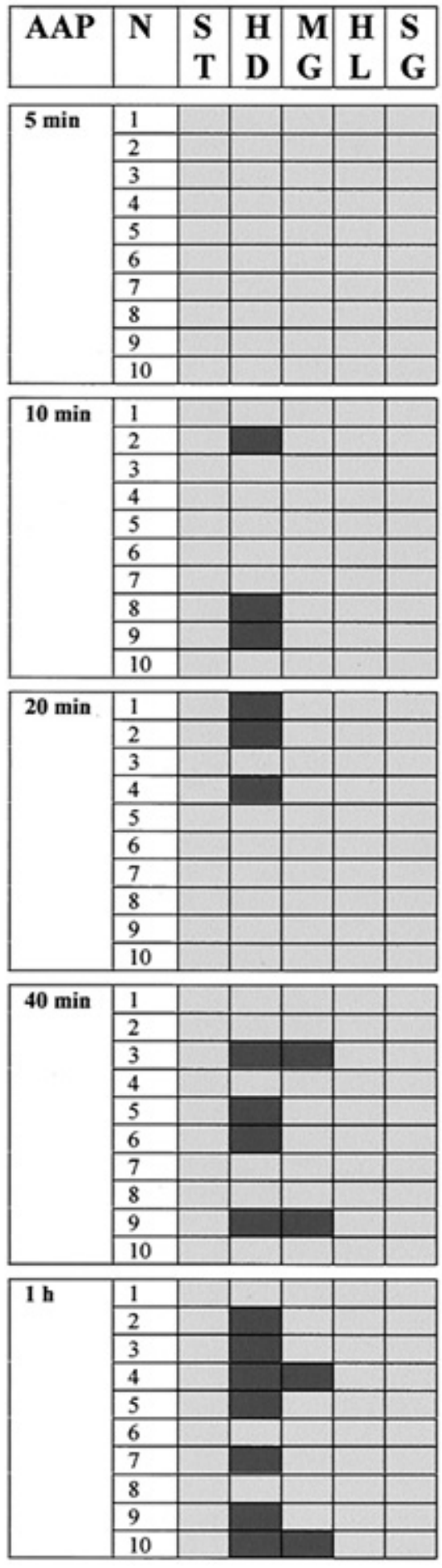
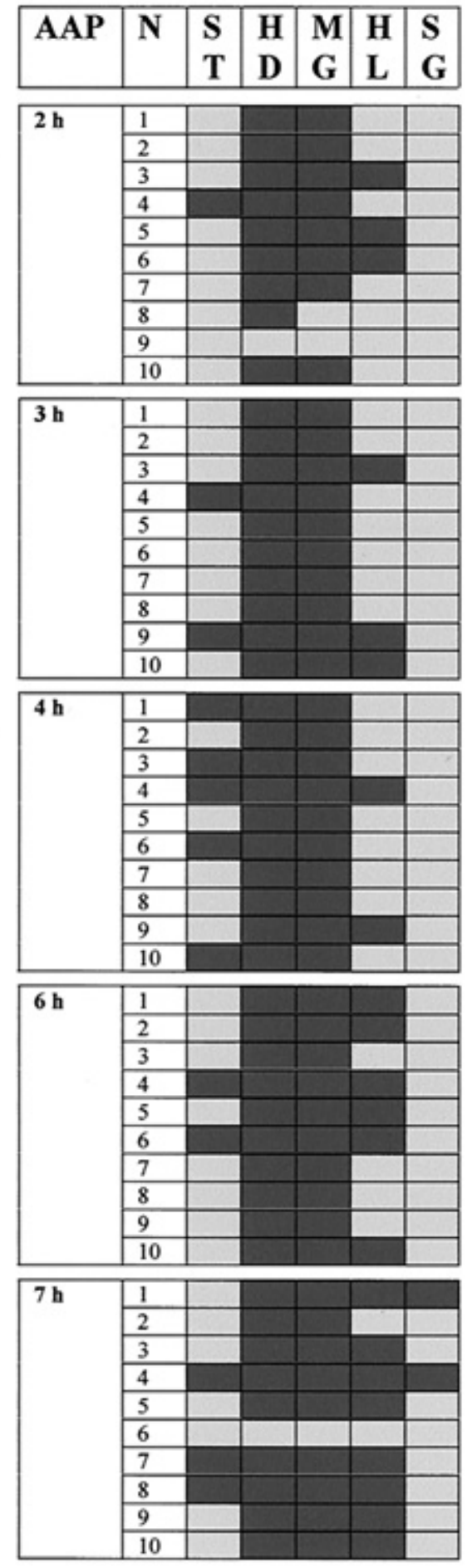
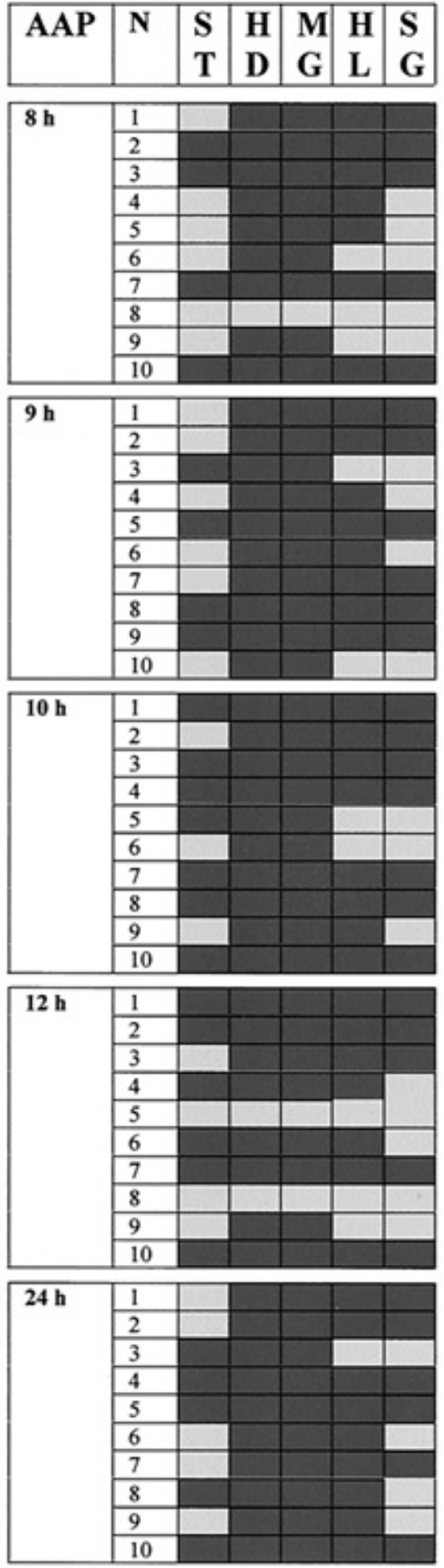

Fig. 3. Time course of Tomato yellow leaf curl virus (TYLCV) translocation as analyzed by subjecting stylets (ST), head (HD), midgut (MG), hemolymph (HL), and salivary glands (SG) of single whiteflies to polymerase chain reaction (PCR). Whiteflies were caged with infected tomato plants for the acquisition access period indicated. At each time, 10 whiteflies (numbered 1 to 10) were dissected, and the relevant organs were subjected to PCR. The results obtained as in Figure 2 were scored as follows; white box indicates viral DNA not detectable and black box indicates TYLCV DNA detected. 


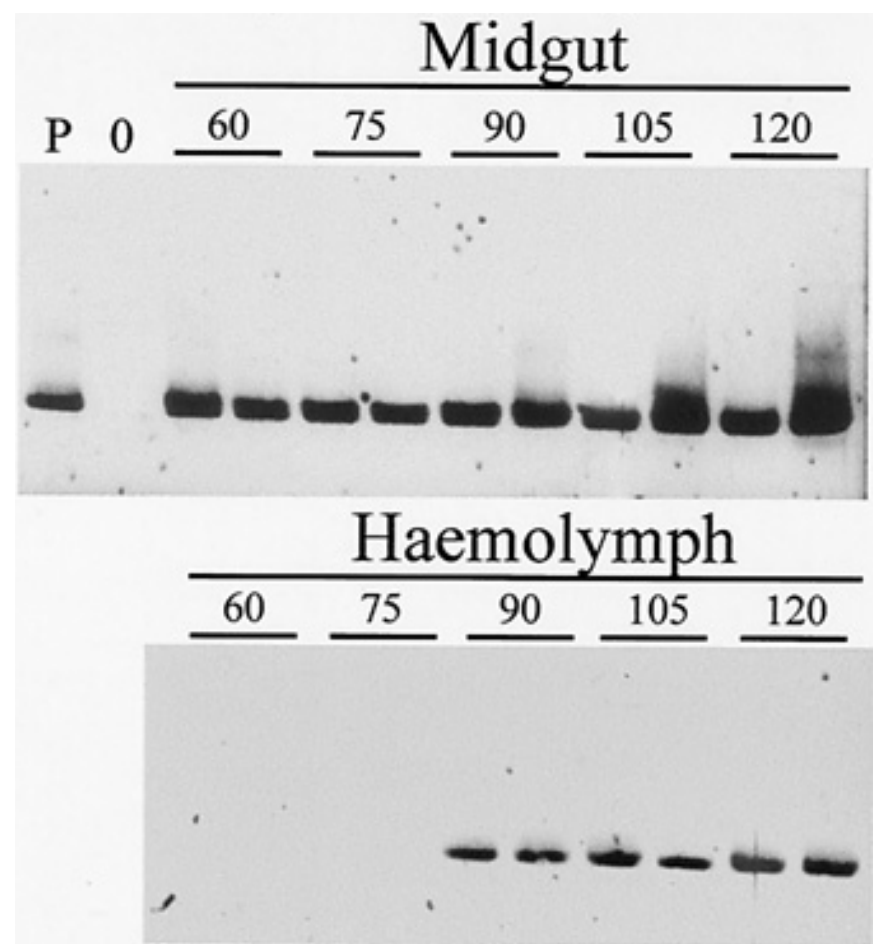

Fig. 4. Passage of Tomato yellow leaf curl virus (TYLCV) from the digestive tract to the hemolymph. Midgut and hemolymph of whiteflies were subjected to polymerase chain reaction (PCR) at 60, 75, 90, 105, and $120 \mathrm{~min}$ after the insects were caged with infected tomato plants. Two replicates representing one insect each were analyzed. The products of the reaction by primers were examined by agarose gel electrophoresis, blotted and hybridized with a virusspecific DNA probe. $\mathrm{P}=$ plasmid $\mathrm{pTYH} 20.7$ containing the TYLCV DNA clone. $0=$ no DNA in the PCR reaction.

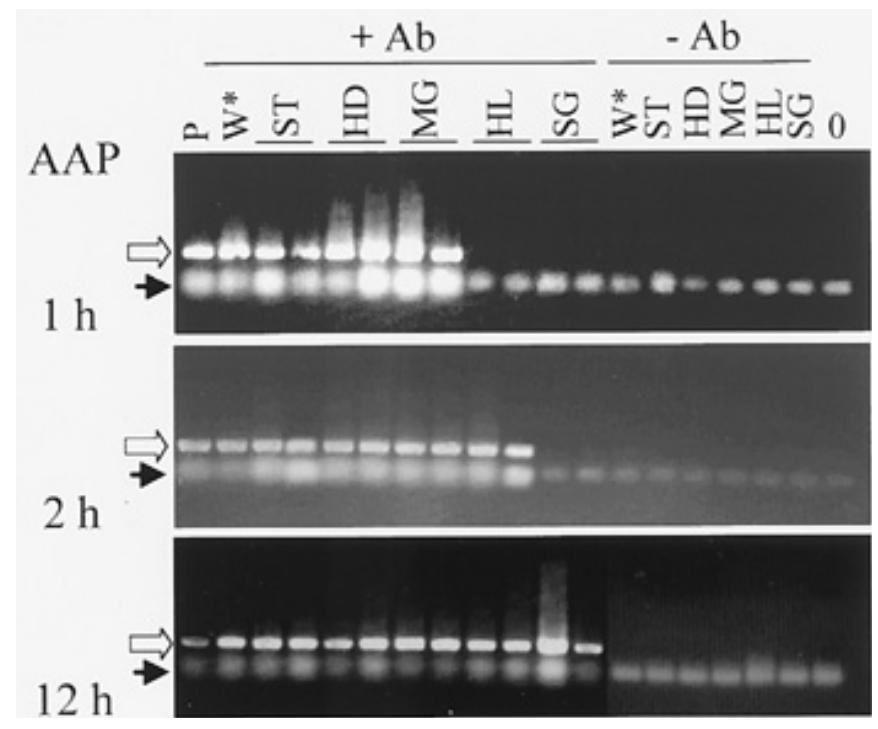

Fig. 5. Detection of Tomato yellow leaf curl virus (TYLCV) DNA associated with the virus coat protein (CP) in whitefly tissues by immunocapturepolymerase chain reaction (PCR), as a function of the length of the acquisition access period (AAP). After the AAPs indicated, the stylets (ST), head (HD), midgut (MG), hemolymph (HL), and salivary glands (SL) were dissected from three groups of 25 insects each, and extracts of each of the pooled 25 organs were prepared. Two extracts were incubated in tubes coated with the $\mathrm{CP}$ antibody $(+\mathrm{Ab})$, one extract was incubated with nontreated test tubes $(-\mathrm{Ab})$. The virus bound to the antibody was subjected to PCR using the TYLCV primer pair V61 and C473. The reaction products were examined by agarose gel electrophoresis and stained with ethidium bromide. $\mathrm{P}=$ plasmid $\mathrm{pTYH} 20.7$ containing the TYLCV DNA clone; $\mathrm{W}^{*}=$ extract of 20 viruliferous whiteflies; $0=$ no DNA in the PCR reaction. The thick arrow points to the $\approx 400$-bp reaction product; thin arrow points to the position of the primers.
$21 \mathrm{~h}$ (10). This change may be due to modifications that occurred in the virus or in the vector population.

Information related to the temporal passage of the virus in the various tissues participating in the transmission process is scarce. TYLCSV was detected by hybridization in DNA extracted from the head (including the first segment of the thorax containing the salivary glands) and the abdomen of $B$. tabaci after a 24-h AAP (5), a time period greater than the latent period (6). The first attempt to measure the velocity of circulation of a geminivirus used PCR to track the New World bipartite begomovirus SLCV from the beginning of access feeding until it was excreted with the saliva (33). In this study, we have followed TYLCV DNA during its transit in the circulative pathway. We have investigated TYLCV translocation by subjecting organs of 10 insects to PCR to obtain a representative image of the presence of the virus in organs of an insect population at a given time after the beginning of the AAP.

The stylets were pooled from the head, and the salivary glands (primary and secondary) were dissected from the base of the head. Consequently, the only site in the dissected head the virus transited through was a small portion of the esophagus. The midgut was used after the hindgut was discarded. Hemolymph was collected from the thorax where the esophagus is very small and the midgut is far away. We are confident that the hemolymph sampled was devoid of contamination from virus leaking from the gut as a result of the dissection. We never found hemolymph with TYLCV DNA in the early AAPs (up to $1 \mathrm{~h}$; Fig. 3) when virus was already detected in the midgut. Even later (from 2 to $6 \mathrm{~h}$ ), the number of hemolymph samples with viral DNA was always lower than the number of midgut samples.

Detection of TYLCV in the insect stylets was erratic. We do not think that this was because the viral DNA was not amenable to PCR. Rather, we believe that the plant sap-containing virus is quickly ingested due to differences in pressure between plant and

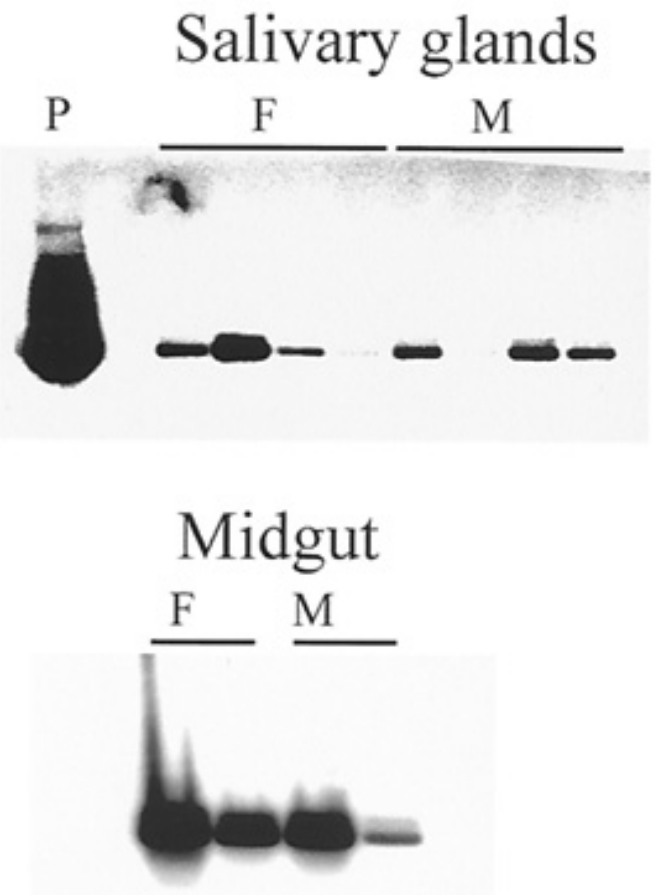

Fig. 6. Presence of Tomato yellow leaf curl virus (TYLCV) in the digestive tract and in the hemolymph of female and male whiteflies, after a 7-h acquisition access period. The midgut and salivary glands of females $(\mathrm{F})$ and males (M) was subjected to polymerase chain reaction. Four (salivary glands) or two (midgut) replicates representing one insect each were analyzed. The products of the reaction were subjected to agarose gel electrophoresis, blotted and hybridized with a virus-specific DNA probe. $\mathrm{P}=$ plasmid pTYH20.7 containing the TYLCV DNA clone. 
insect and to a reflex mechanism occurring when the insect is removed from the plant. Therefore, the head represents a better object to detect virus acquisition. TYLCV was detected in the head of whiteflies as early as after a 10-min AAP. SLCV was detected by PCR of B. tabaci homogenates after a 30-min AAP; however, shorter AAPs were not tested (33). The passage of TYLCV from esophagus to midgut is rather rapid, probably because it does not have to cross membranes. TYLCV-DNA was detected in the midgut approximately $30 \mathrm{~min}$ after it was first found in the head of the insect. At this point, some of the virus might be excreted; for example SLCV was found in honeydew after an 8-h AAP (33). We do not know whether TYLCV is present in all parts of the gut or whether it is confined to a particular compartment (filter chamber, ascending or descending midgut, caeca). Immunolocalization of two New World bipartite begomoviruses (Tomato mottle virus [ToMoV] and Cabbage leaf curl virus $[\mathrm{CaLCV}])$ in whiteflies has indicated that these viruses were present mainly in the filter chamber and in the anterior part of the midgut (22).

The crossing of TYLCV from the midgut to the hemolymph is surprisingly fast. The virus reached the hemolymph $30 \mathrm{~min}$ after it was first detected in the midgut, $90 \mathrm{~min}$ after the beginning of acquisition feeding. SLCV was also found in the hemolymph of $B$. tabaci after a 2-h AAP (33). We do not know whether the crossing of the gut is passive or whether it is an active process involving specialized receptors as in aphids $(15,16)$. The passage of geminiviruses in the hemolymph of their whitefly vector seems a critical step in the virus circulative pathway. During this relatively long period, viruses are in the midst of a hostile environment where they may be subject to degradation by cells and enzymes. To avoid degradation, it seems that geminiviruses, like luteoviruses in aphids (35), interact with chaperonins produced by the insect vector endosymbiotic bacteria and excreted in the hemolymph (26).

TYLCV was detected in the salivary glands approximately $5.5 \mathrm{~h}$ after it was first detected in the hemolymph, Seven hours after the beginning of the AAP, approximately $1 \mathrm{~h}$ before the insects were able to infect tomato plants. Therefore, it seems that once the virus reaches the salivary gland, it is almost immediately excreted into the salivary pump and from there into the plant with the saliva. As a comparison, SLCV was detected in the excreted saliva after an 8-h AAP (33). Reaching the salivary duct implies crossing several cell walls that may constitute selective barriers as in aphids (15).

The temporal virus detection sequence was always the same, reflecting the polarity of virus translocation in the insect. In all 150 insects examined in the experiment summarized in Figure 3 (and in any all instances), we never detected the virus in a temporal order other than head-midgut-hemolymph-salivary glands. The timing of translocation of TYLCV was basically similar to that of SLCV (33), indicating that the circulation of begomoviruses may be independent of the identity of the virus (as long as it is transmissible) and of the geographical origin of B. tabaci.

Females transmit TYLCV with higher efficiency than males (10). One of the possible hypotheses we tested was that TYLCV reaches the salivary glands of females earlier than that of the males. PCR analysis indicated that TYLCV DNA was present in the salivary gland of both females and males $7 \mathrm{~h}$ after the beginning of acquisition feeding. It is possible that differences in virus amounts in the salivary gland are the cause for the differential inoculation abilities of males and females.

We do not know whether begomoviruses circulate in $\mathrm{B}$. tabaci as encapsidated virions. The CP of two Old World bipartite begomoviruses ToMoV and CaLCV has been detected in the midgut and the salivary glands of B. tabaci anatomical sections by immunofluorescent labeling, suggesting that encapsidated virions were present in these tissues (22). Whereas PCR can account only for viral DNA (single-stranded and double-stranded), immunocapture-PCR allows detection of viral DNA associated with the
CP in insect extracts $(13,23)$. Our results show that the TYLCV translocation timing obtained by PCR and by immunocapturePCR overlap, although the later analysis was less extensive than the former. We never detected only viral DNA or CP unattached at any time during the circulative pathway. These results suggest that at least part of the virus is moving as a virion.

TYLCV has several features of an insect pathogen. Acquired by whiteflies after emergence, the virus (DNA and infectivity) remains associated with the insect for its entire adult life. This longterm relationship is associated with a decrease in the host life expectation and fecundity (34). TYLCV invades the B. tabaci reproductive system (14) and may be transmitted to other insects in a sexual-related manner (13). Therefore, it seems that most of the virus acquired by the insect leaves the circulative pathway at some unknown point and is stored in unknown tissues for periods of time much longer than the latent period. Similarly, SLCV (8) and other begomoviruses $(5,27)$ are present in the insect as infective entities much longer than the latent period. Hence, the circulative pathway is only one of the tracks begomoviruses may follow in their acquired insect vector.

\section{ACKNOWLEDGMENTS}

Supported by Grant 95-168 from The U.S.-Israel Binational Science Foundation (BSF).

\section{LITERATURE CITED}

1. Atzmon, G., van Hoss, H., and Czosnek, H. 1998. PCR-amplification of tomato yellow leaf curl virus (TYLCV) from squashes of plants and insect vectors: Application to the study of TYLCV acquisition and transmission. Eur. J. Plant Pathol. 104:189-194.

2. Azzam, O., Frazer, J., Delarosa, D., Beaver, J. S., Ahlquist, P., and Maxwell, D. P. 1994. Whitefly transmission and efficient ssDNA accumulation of bean golden mosaic geminivirus require functional coat protein. Virology 204:289-296.

3. Bandla, M. D., Campbell, L. R., Ullman, D. E., and Sherwood, J. L. 1998. Interaction between tomato spotted wilt virus Tospovirus (TSWV) glycoproteins with a thrips midgut protein, a potential cellular receptor for (TSWV). Phytopathology 88:98-104.

4. Briddon, R. W., Pinner, M. S., Stanley, J., and Markham, P. G. 1990. Geminivirus coat protein gene replacement alters insect specificity. Virology 177:85-94.

5. Caciagli, P., and Bosco, D. 1997. Quantitation over time of tomato yellow leaf curl geminivirus DNA in its whitefly vector. Phytopathology 87:610-613.

6. Caciagli, P., Bosco, D., and Al-Bitar, L. 1995. Relationships of the Sardinian isolate of tomato yellow leaf curl geminivirus with its whitefly vector Bemisia tabaci Gen. Eur. J. Plant Pathol. 101:163-170.

7. Cohen, S. 1993. Sweet potato whitefly biotypes and their connection with squash silver leaf. Phytoparasitica 21:174.

8. Cohen, S., Duffus, J. E., Larsen, R. C., Liu, H. Y., and Flock, R. A. 1983. Purification, serology, and vector relationships of squash leaf curl virus, a whitefly-transmitted geminivirus. Phytopathology 73:1669-1673.

9. Cohen, S., Duffus, J. E., and Liu, H. Y. 1989. Acquisition, interference, and retention of cucurbit leaf curl viruses in whiteflies. Phytopathology 79:109-113.

10. Cohen, S., and Nitzany, F. E. 1966. Transmission and host range of the tomato yellow leaf curl virus. Phytopathology 56:1127-1131.

11. Czosnek, H., and Laterrot, H. 1997. A worldwide survey of tomato yellow leaf curl viruses. Arch. Virol. 142:1391-1406.

12. Fauquet, C. M., Maxwell, D. P., Gronenborn, B., and Stanley, J. 2000. Revised proposal for naming geminiviruses. Arch. Virol. 145:1743-1761.

13. Ghanim, M., and Czosnek, H. 2000. Tomato yellow leaf curl geminivirus (TYLCV-Is) is transmitted among whiteflies (Bemisia tabaci) in a sexrelated manner. J. Virol. 74:4738-4745.

14. Ghanim, M., Morin, S., Zeidan, M., and Czosnek, H. 1998. Evidence for transovarial transmission of tomato yellow leaf curl virus by its vector the whitefly Bemisia tabaci. Virology 240:295-303.

15. Gildow, F. E. 1987. Virus-membrane interactions involved in circulative transmission of luteoviruses by aphids. Cur. Topics Vector Res. 4:93-120.

16. Gildow, F. E. 1993. Evidence for receptor-mediated endocytosis regulating luteovirus acquisition by aphids. Phytopathology 83:270-277.

17. Gildow, F. E., and Gray, S. M. 1993. The aphid salivary gland basal lamina as a selective barrier associated with vector-specific transmission of 
barley yellow dwarf luteoviruses. Phytopathology 83:1293-1302.

18. Harris, K. F., Pesic-Van Esbroeck, Z., and Duffus, J. E. 1995. Anatomy of a virus vector. Pages 289-318 in: Bemisia 1995: Taxonomy, Biology, Damage, Control and Management. D. Gerling and R. Mayer, eds. Intercept, Andover, Hans, U.K.

19. Harris, K. F., Pesic-Van Esbroeck, Z., and Duffus, J. E. 1996. Morphology of the sweet potato whitefly, Bemisia tabaci (Homoptera, Aleyrodidae) relative to virus transmission. Zoomorphology 116:143-156.

20. Harrison, B. D. 1985. Advances in Geminivirus research. Annu. Rev. Phytopathol. 23:55-82.

21. Höfer, P., Bedford, I. D., Markham, P. G., Jeske, H., and Frischmuth, T. 1997. Coat protein gene replacement results in whitefly transmission of an insect nontransmissible geminivirus isolate. Virology 236:288-295.

22. Hunter, W. B., Hiebert, E., Webb, S. E., Tsai, J. H., and Polston, J. E. 1998. Location of geminiviruses in the whitefly Bemisia tabaci (Homoptera: Aleyrodidae). Plant Dis. 82:1147-1151.

23. Jacobi, V., Bachand, G. D., Hamelin, R. C., and Castello, J. D. 1998. Development of a multiplex immunocapture RT-PCR assay for detection and differentiation of tomato and tobacco mosaic tobamoviruses. J. Virol. Methods 74:167-178.

24. Mansour, A., and Al-Musa, A. 1992.Tomato yellow leaf curl virus: Host range and vector-virus relationships. Plant Pathol. 41:122-125.

25. Mehta, P., Wyman, J. A., Nakhla, M. K., and Maxwell, D. P. 1994. Transmission of tomato yellow leaf curl geminivirus by Bemisia tabaci (Homoptera: Aleyrodidae). J. Econ. Entomol. 87:1291-1297.

26. Morin, S., Ghanim, M., Zeidan, M., Czosnek, H., Verbeek, M., and van den Heuvel, J. F. J. M. 1999. A GroEL homologue from endosymbiotic bacteria of the whitefly Bemisia tabaci is implicated in the circulative transmission of Tomato yellow leaf curl virus. Virology 30:75-84.

27. Muniyappa, V., Venkatesh, H. M., Ramappa, H. K., Kulkarni, R. S., Zeidan, M., Tarba, C.-Y., Ghanim, M., and Czosnek, H. 2000. Tomato leaf curl virus from Bangalore (ToLCV-Ban4): Sequence comparison with Indian ToLCV isolates, detection in plants and insects, and vector relationships. Arch. Virol. 145:1583-1598.

28. Nation, J. L. 1983. A new method using hexamethyldisilazane for preparation of soft insect tissues for scanning electron microscope. Stain Technol. 58:347-351.

29. Navot, N., Ber, R., and Czosnek, H. 1989. Rapid detection of tomato yellow leaf curl virus in squashes of plant and insect vectors. Phytopathology 79:562-568.

30. Navot, N., Pichersky, E., Zeidan, M., Zamir, D., and Czosnek, H. 1991. Tomato yellow leaf curl virus: A whitefly-transmitted geminivirus with a single genomic component. Virology 185:151-161.

31. Navot, N., Zeidan, M., Pichersky, E., Zamir, D., and Czosnek, H. 1992. Use of the polymerase reaction to amplify tomato yellow leaf curl virus DNA from infected plants and viruliferous whiteflies. Phytopathology 82:1199-1202.

32. Noris, E., Vaira, A. M., Caciagli, P., Masenga, V., Gronenborn, B., and Accotto, G. P. 1998. Amino acids in the capsid protein of tomato yellow leaf curl virus that are crucial for systemic infection, particle formation, and insect transmission. J. Virol. 72:10050-10057.

33. Rosell, R. C., Torres-Jerez, I., and Brown, J. K. 1999. Tracing the geminivirus-whitefly transmission pathway by polymerase chain reaction in whitefly extracts, saliva, hemolymph, and honeydew. Phytopathology 89:239-246.

34. Rubinstein, G., and Czosnek, H. 1997. Long-term association of tomato yellow leaf curl virus (TYLCV) with its whitefly vector Bemisia tabaci: Effect on the insect transmission capacity, longevity and fecundity. J. Gen. Virol. 78:2683-2689.

35. van den Heuvel, J. F. J. M., Verbeek, M., and van der Wilk, F. 1994. Endosymbiotic bacteria associated with circulative transmission of potato leafroll virus by Myzus persicae. J. Gen. Virol. 75:2559-2565.

36. Zeidan, M., and Czosnek, H. 1991. Acquisition of tomato yellow leaf curl virus by the whitefly Bemisia tabaci. J. Gen. Virol. 72:2607-2614. 